\title{
ASSESSMENT OF SELECTED MUNICIPALITIES' PERFORMANCE OF CITIZEN-CENTRIC INVESTMENT PLANNING, AND SUPPORT FOR YOUTH PROGRAMMING IN KOSOVO
}

\author{
Florentina Hajdari- Hajra \\ Ph.D. Student, Faculty of Contemporary Social Sciences, \\ South East European University, Tetovo, North Macedonia \\ florentina.hajdari@gmail.com \\ Artan Binaku \\ Ph.D. Student, Faculty of Contemporary Social Sciences, \\ South East European University, Tetovo, North Macedonia \\ artan.binaku@gmail.com
}

\begin{abstract}
This paper aims to assess selected municipalities' performance of citizen-centric investment planning, governance and transparency, financial management, and support for youth programming in Kosovo. In completing this assessment, the Municipal Performance Management System of the Ministry of Local Government Administration (MLGA) in Kosovo was utilized. Selected municipalities are based on the Municipal Performance Report of 2019. Eight from Albanian majority municipalities in the top ranking, and two municipalities with higher scores from minority municipalities. The paper aims to highlight three critical local government issues in ten selected municipalities: 1) The way of governing municipalities assessed according to the applicable legislation and 2) The provision of services in terms of quantity and quality, when possible and 3) Youth-oriented capacity building for municipal staff for better youth services (Ministry of Local Government Administration, 2019). The paper will produce findings on capacity building needs and support needed on youth and citizen-centric
\end{abstract}


investment and capacity building needs. A non-exhaustive list of needed capacities is produced, while the findings from the evaluation will be used to develop a capacity-building manual for municipal staff on youth-oriented municipal services.

Keywords: Municipalities, investment, planning, capacity, youth.

\section{INTRODUCTION}

In 2009, Kosovo Parliament approved the Law on Empowerment and Participation of Youth. The Law intends to empower youth in taking part in the central and local decision processes, with the final aim of their empowerment. The Law aspires to 'develop a democratic society, to improve the quality of life of youth and their social status.' (Law on Empowerment and Participation of Youth, 2009). The Law provides essential 'responsibilities for strengthening the youth sector in Kosovo and supporting youth participation in decisionmaking and central and local government institutions responsibilities' (Ibid). These institutional obligations are related to young people and youth organizations in relevant areas regulated by this Law, voluntary work, and informal education'. (Ibid). The Law above provides the legal basis for establishing local youth organizations that allow youth participation at central and local levels in Kosovo, meaning Local Youth Action Councils and Central Youth Action Councils. The Law also stipulates the responsibilities that municipalities have in the process; concretely, article 7.1 obliges municipalities to provide youth organizations with financial resources, space, support for informal education, and the development of municipal youth policies. In addition to the Law above, the Law on Local Government approved in 2008, in its Chapter IX, Direct Democracy and Citizen Participation Mechanisms, stipulates institutional responsibilities for public information and consultation.

Specifically, 'municipalities are obliged to inform the citizens of the Municipality of any necessary plans or programs of public interest'. (Law on Local Self-Governance,2008) On top of the information sharing obligation that municipalities and institutions in Kosovo have, they are obliged to incorporate public and youth in decision-making processes when drafting public policies and developing budgets. Furthermore, 'municipal Assemblies shall adopt municipal regulation promoting the transparency of the municipalities' legislative, executive, and administrative bodies, enhancing public participation in the decision-making at the local level, and facilitating public access to official documents of the municipalities'. (Ibid). Further, the Ministry of Culture, Youth and Sports of Kosovo has approved an Administrative 
Instruction AI 10/2010 on the Volunteer Work of Youth and sets out procedures for youth and institutions' obligations to facilitate these obligations.

In assessing the capacities of ten municipalities in citizen-centric investment planning, governance and transparency, financial management, and support for youth programming, ten municipalities have been surveyed and provided information on these themes. The questionnaire contained municipal competencies, capacity needs, budget, and which fields the municipalities need assistance from. The questionnaire had eight questions in total, answered in-person, including questions on municipal youth-oriented services/facilities and budget allocations, training needs of municipal staff, youth volunteers profile needed, and the capacity to supervise and technically accept subgrants that contain capital investments. Through these questions, evaluation on capacities has been assessed. In addition, meeting with mayors, deputy mayors, directors of education, youth officers, and youth coordinators were held in ten municipalities. Municipalities involved in the exercise were Gllogoc, Hani Elezit, Rahovec Skenderaj, Vushtrri, Junik, Kaçanik, Ferizaj, Ranillug, and Zveçan. The report aims to highlight three key issues: 1) The way of governing municipalities assessed according to the applicable legislation and 2) The provision of services in terms of quantity and quality, when possible and 3) Youth-oriented capacity building for municipal staff for better youth services (Ministry of Local Government Administration, 2019).

MLGA's Municipal Performance Management System (MPMS) was used to select municipalities. MPMS has measured the performance of municipalities in different 19 fields with 119 measurement indicators, covering areas such as transparency, financial management, service delivery, environmental protection, and youth-oriented planning, decision-making, and activities. The ten municipalities include eight Albanian-majority municipalities and two minority municipalities.

\section{MUNICIPALITIES PERFORMANCE AND NEEDS ASSESSMENT}

Nineteen fields of the municipal performance management shown in the Municipal Performance Report system summarize a reasonably wide range of municipal competencies. (Ministry of Local Government Administration, 2020).) Furthermore, they express the rights and obligations that municipalities exercise to serve citizens based on legal competencies (Ibid). The indicators were used to provide considerable information on the level of services offered. The data obtained from this system 'provide clear indications to the municipal management and stakeholders about the interventions, the extension of priorities, and the achievement of the intended objectives' (Municipal Performance Management System, 2019). 
Table 1. shows the best ten ranked municipalities from 38 in total, on which further assessment has been done on this research to analyze the capacities and needs of the best-ranked municipalities when it comes to youth-oriented projects.

\begin{tabular}{|c|c|c|c|c|}
\hline NO & Municipality & $\begin{array}{c}\text { Performance } \\
\text { Scores 2019 }\end{array}$ & $\begin{array}{c}\text { Youth } \\
\text { Population } \\
\mathbf{( 1 5 - 1 9 )}\end{array}$ & $\begin{array}{c}\text { Youth population } \\
\mathbf{( 2 0 - 2 4 )}\end{array}$ \\
\hline 1 & Ranillug & 31 & 308 & 328 \\
\hline 2 & Junik & 63 & 572 & 552 \\
\hline 3 & Hani i Elezit & 53 & 900 & 831 \\
\hline 4 & Zvecan & 37 & 0 & 0 \\
\hline 5 & Kaçanik & 59 & 3393 & 3161 \\
\hline 6 & Skenderaj & 57 & 5243 & 5088 \\
\hline 7 & Rahovec & 68 & 6253 & 6380 \\
\hline 8 & Gllogovc & 72 & 5886 & 6607 \\
\hline 9 & Vushtrii & 57 & 7085 & 9850 \\
\hline 10 & Ferizaj & 55 & 10985 & 38027 \\
\hline & TOTAL & & 40625 & \\
\hline
\end{tabular}

Table 1: Municipalities by Performance Score, Youth Population and co-financing amount- Data on population used from the Kosovo Agency of Statistics-2011-Country Census

From the 19 fields of performance measurement, this report will focus on the ten selected municipalities achievements and municipal performances on five domains:

- Municipal transparency

- Equality employment, social services, and public spaces

- Culture, youth, and sports

- Gender representation

- Pre-university education

Besides the abovementioned fields from the Performance Management System, the report will evaluate the level of:

- Pieces of training are needed of the municipal staff.

- Youth volunteers' profiles to improve municipal provided services

- Youth-oriented budgets

- Present municipal youth facilities

- Capacity on evaluating, supervising, and technical acceptance of sub-projects related to youth projects

According to the percentages presented in Figure 1, the Municipality with the 'highest performance is Gllogoc with 77.04\%, followed by Hani i Elezit with 75.78 and Rahovec with $75.20 \%$. It should be noted that with the review of indicators for this reporting year, the 
performance of many service indicators is measured per capita in the Municipality or per square kilometer of the respective Municipality' (Municipal Performance Report, 2020).

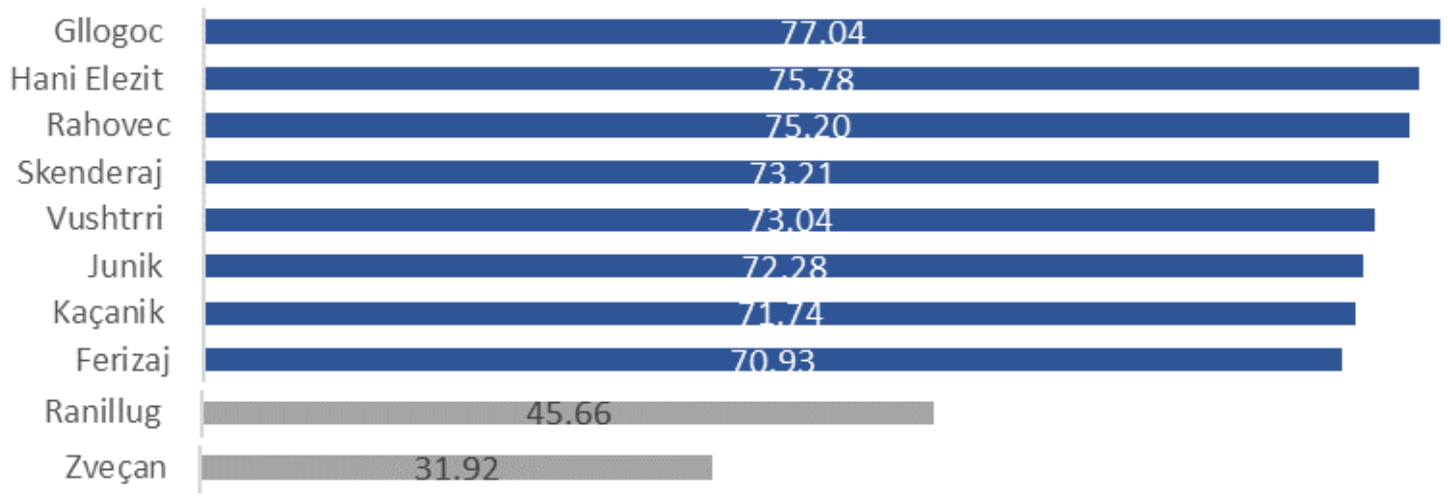

\section{Municipal Transparency}

This area has seven indicators to ensure access to municipal data, attend assembly meetings, raise 'information standards through websites, budget transparency, and public procurement. (Ibid) The overall performance achieved in transparency is 72.93\%' (Municipal Performance Report, 2019). Vushtrri (100\%), Kaçanik (100\%), Gllogoc (100\%), Rahovec (98.95\%), Ferizaj (98.13\%), Hani i Elezit (92.00\%), Skenderaj (85.08\%) while the municipalities who lack in Municipal Transparency are Ranilluga (53.25\%) and Zvecan with only $(0.15 \%)$.

\section{Equality in Employment, Social and Family Services}

This field of 'two outcomes and four indicators cover the representation of different groups in municipal employment' and the social services of the most disadvantaged municipalities. (Ibid) Within employment, indicators measure the level of employment of persons with disabilities in municipal institutions and the percentage of inclusion of nonmajority communities. (Ibid) Overall performance in this field is $57.70 \%$.

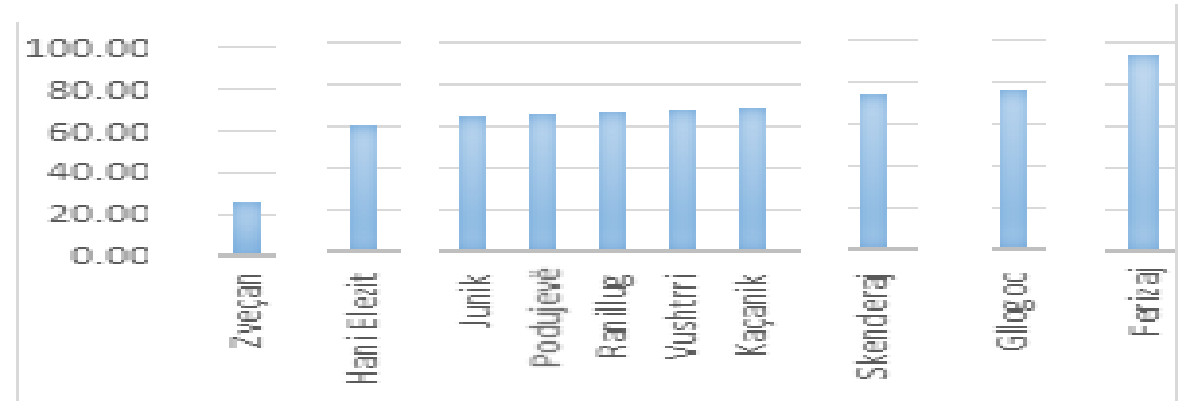




\section{Culture, Youth, and Sports}

Within this field, 'municipal cultural, youth and sports activities are measured as one of the own competencies of municipalities' (Ibid). Therefore, the area also covers services provided by municipalities related to culture, youth, and sports, including sports facilities.

This 'field measures performance by comparing it to the number of inhabitants for' more balanced towards municipalities with many inhabitants and fewer inhabitants. This field has an overall performance of $67.99 \%$ (Ibid). Thus, there is no significant difference from the ten municipalities selected that must be highlighted.

\section{$\%$ of indicators in the field of culture, youth and sports}

Citizen participation in cultural, youth and sports
activities

Activities of culture, youth and sports, organized by the municipal budget

Premises for sports activities by number of inhabitants
57.37

\subsection{3}

\section{Gender Representation}

Gender representation is now more widely measured, including the access of both genders to social and economic development programs and municipal activities. Also, 'the indicators measure the degree of representation of both genders in local institutions, bodies of municipal assemblies' (Ibid). However, despite the progress of municipalities over the years in ensuring equal representation in the bodies of assemblies and municipal committees, the data for specific indicators minimize the percentage in this area, making it relatively low, $38.24 \%$. Gender representation in local councils is deficient, and the vast majority of municipalities do not have any women leading these councils. This also considers that almost half of the municipalities do not have functional local councils, as shown in the third area. Furthermore, gender representation in the names of municipal roads is deficient, and 'the registration of property in the name of a woman or both genders (husband or brothers and sisters)' (Ibid). From the ten selected municipalities, $\%$ achieved by municipalities - gender representation varies from $29.8 \%$ Ranillug to $59.1 \%$ Junik. 
Gender-responsive budgeting and spending turn 'out to be done by just over half of the municipalities. However, there is a great need for training in this regard and the will of municipalities to understand the importance of this issue. Gender equality in budgeting for subsidies and the program of the Municipality is at a very low level of $36.33 \%$ and this should be raised to the level of equality of 50\%'. (Ministry of Local Governance Administration, 2020). Women, including young women, are underrepresented in decision-making and employment in public institutions in Kosovo. Young women who are "very interested" in political issues account for $16.1 \%$ compared to $18.7 \%$ of young men, indicating future disengagement of women in decision-making in public institutions. In 2018, among 6,148 civil servants employed in 38 municipal administrations, only $33.4 \%$ were women.

\section{Pre-University Education}

This indicator aims at 'results in spaces for kindergartens and schools equipped with internet cabinets, energy efficiency measures, recruitment of educational staff, teacher licensing, concretization tools, school equipment with teaching aids, ICT cabinets, and school safety conditions'. This field has an overall performance at the level of $66.60 \%$ (Ibid). In general, 'in education indicators, the data reported by municipalities has not been complete, so the percentages obtained may represent a relative accuracy value'. (Ibid) This indicator is followed up with interviews with municipal officials focusing on Youth facilities, as explained below.

Besides the abovementioned fields assessment from the MLGA Performance Management System, structured interviews are being held (See list of interviews in Annex 1.) in all ten municipalities to assess the following fields of interest: Municipal Youth budgeting; Human resources needed/Youth volunteers' profiles; Present municipal youth facilities; Training needed of the actual municipal staff, and since the subprojects can include minor civil works in form of rehabilitation of buildings and public spaces in which case special conditions are required in the preparation of documentation and supervision, selected municipalities have to: Facilitate capital investment subgrant beneficiaries to obtain environmental, construction and/or other official permits that may be required and making sure that the proposed investments are in line with their local development plans; Conducting regular supervision of capital investments sub-projects and reporting to the Ministry about any irregularities in the implementation, including those related to environmental protection; Appointing engineering staff to facilitate the evaluation of subprojects if needed and; Carrying out operations and 
SEEU Review Volume 16 Issue 2

maintenance for any municipal infrastructure or equipment (such as parks, playground equipment.

In the table below, these aspects of municipal capacities have been summarized: 


\begin{tabular}{|c|c|c|c|c|c|}
\hline Municipality & $\begin{array}{l}\text { Trainings needed of } \\
\text { the municipal staff }\end{array}$ & $\begin{array}{l}\text { Youth volunteers to improve municipally } \\
\text { provided services }\end{array}$ & $\begin{array}{l}\text { Youth } \\
\text { oriented } \\
\text { budgets }\end{array}$ & $\begin{array}{l}\text { Present municipal } \\
\text { youth facilities and } \\
\text { structures }\end{array}$ & $\begin{array}{l}\text { Capacity for technical supervision of } \\
\text { subprojects }\end{array}$ \\
\hline Hani Elezit & $\begin{array}{l}\text { Volunteerism; Local } \\
\text { economic development } \\
\text { Gender Equality; } \\
\text { Inclusion of Youth in } \\
\text { decision-making } \\
\text { processes; } \\
\text { internships }\end{array}$ & $\begin{array}{l}\text { Construction engineer; Social } r \text { worker } \\
\text { Environmentalist; } \\
\text { development/management (assigned for youth- } \\
\text { oriented projects) }\end{array}$ & $1.29 \%$ & $\begin{array}{l}\text { Sports hall; Career } \\
\text { orientation center; Youth } \\
\text { center; Local youth action } \\
\text { councils }\end{array}$ & Yes \\
\hline Rahovec & $\begin{array}{l}\text { Volunteerism; Local } \\
\text { economic development; } \\
\text { Inclusion of Youth in } \\
\text { decision-making } \\
\text { processes; } \\
\text { internships }\end{array}$ & $\begin{array}{l}\text { Environmentalist; Social worker; } \\
\text { Project writers }\end{array}$ & $7,079 \%$ & $\begin{array}{llr}\text { Sports } & \text { hall; } & \text { Cultural; } \\
\text { Center } & \text { Youth } & \text { center; } \\
\text { Local youth } & \text { action } \\
\text { councils } & & \end{array}$ & Yes \\
\hline Skenderaj & $\begin{array}{l}\text { Volunteerism; Local } \\
\text { economic development } \\
\text { Gender Equality; } \\
\text { Inclusion of Youth in } \\
\text { decision-making } \\
\text { processes; Paid } \\
\text { internships; Inclusion of } \\
\text { people with disabilities }\end{array}$ & $\begin{array}{l}\text { Construction engineer; } \quad \text { Finances; } \\
\text { Environmentalist; Social worker; Project } \\
\text { development/management (assigned for youth- } \\
\text { oriented projects); Public and social media }\end{array}$ & $2.4 \%$ & $\begin{array}{llr}\text { Sports } & \text { hall; } & \text { Cultural; } \\
\text { Center } & \text { Youth } & \text { center; } \\
\text { Local } & \text { youth } & \text { action } \\
\text { councils } & & \end{array}$ & No \\
\hline Vushtrri & $\begin{array}{l}\text { Volunteerism; Local } \\
\text { economic development }\end{array}$ & Construction engineer; Ecologist; Architect; & $2.38 \%$ & $\begin{array}{l}\text { Sports hall; Cultural } \\
\text { center; Youth center and }\end{array}$ & No \\
\hline
\end{tabular}

${ }^{1}$ There is no specific budget line for the youth-oriented budgets. The calculation done by the municipalities include specifically the subvention budget line (youth projects supported, youth centers and youth action councils, scholarships provided, etc.) 
SEEU Review Volume 16 Issue 2

\begin{tabular}{|c|c|c|c|c|c|}
\hline & $\begin{array}{l}\text { Gender Equality; } \\
\text { Inclusion of Youth in } \\
\text { decision-making } \\
\text { processes; } \quad \text { Paid } \\
\text { internships; }\end{array}$ & $\begin{array}{l}\text { Social worker; Project development/management } \\
\text { (assigned for youth-oriented projects) }\end{array}$ & & $\begin{array}{l}\text { local youth action } \\
\text { councils. }\end{array}$ & \\
\hline Junik & $\begin{array}{l}\text { Volunteerism; Local } \\
\text { economic development; } \\
\text { Paid internships; } \\
\text { Administration }\end{array}$ & $\begin{array}{l}\text { Construction engineer; Architect; Financial } \\
\text { officers; } \\
\text { Environmentalist; Social worker; } \\
\text { Project development/management (assigned for } \\
\text { youth-oriented projects); Administration }\end{array}$ & $1.07 \%$ & $\begin{array}{l}\text { The youth center, local } \\
\text { youth action council }\end{array}$ & No \\
\hline Zveçan & $\begin{array}{l}\text { Volunteerism; Local } \\
\text { economic development } \\
\text { Inclusion of Youth in } \\
\text { decision making; Paid } \\
\text { internships; Ecology, } \\
\text { promotion of cultural } \\
\text { and historical heritage, } \\
\text { sport }\end{array}$ & $\begin{array}{l}\text { Construction engineer; Environmentalist; Social } \\
\text { worker } \\
\text { Project development/management (assigned for } \\
\text { youth-oriented projects); psychologist; legal } \\
\text { specialists }\end{array}$ & $0.45 \%$ & $\begin{array}{l}\text { Sports hall; Youth center; } \\
\text { Local youth action } \\
\text { council; } \\
\text { University }\end{array}$ & Yes \\
\hline Ranillug & $\begin{array}{lr}\text { Local } & \text { economic } \\
\text { development; } & \text { Inclusion } \\
\text { of Youth in } & \text { decision } \\
\text { making; } & \text { Paid } \\
\text { Internships; } & \end{array}$ & $\begin{array}{l}\text { Construction } \quad \text { engineer; Architect; } \\
\text { Environmentalist; Social worker; Project writers }\end{array}$ & $2.40 \%$ & $\begin{array}{l}\text { Sports hall; Cultural } \\
\text { center; Youth center }\end{array}$ & No \\
\hline Ferizaj & $\begin{array}{l}\text { Volunteerism; Human } \\
\text { Rights; Gender equality; } \\
\text { Local economic } \\
\text { development; Inclusion } \\
\text { of Youth in decision }\end{array}$ & $\begin{array}{l}\text { Environmentalist; } \\
\text { development/management (assigned for youth- } \\
\text { oriented projects) } \\
\text { Social workers }\end{array}$ & $1.15 \%$ & $\begin{array}{l}\text { Sports hall; Cultural } \\
\text { house; Local youth } \\
\text { action council; University }\end{array}$ & Yes \\
\hline
\end{tabular}


SEEU Review Volume 16 Issue 2

\begin{tabular}{|c|c|c|c|c|c|}
\hline & $\begin{array}{lr}\text { making; } & \text { Paid } \\
\text { internships; } & \text { public } \\
\text { services, } & \end{array}$ & & & & \\
\hline Kaçanik & $\begin{array}{l}\text { Volunteerism; Gender } \\
\text { equality; Local } \\
\text { economic development; } \\
\text { Inclusion of Youth in } \\
\text { decision making; Paid } \\
\text { Internships }\end{array}$ & $\begin{array}{l}\text { Construction engineer; Environmentalist; Project } \\
\text { development/management (assigned for youth- } \\
\text { oriented projects) }\end{array}$ & $0.64 \%$ & $\begin{array}{l}\text { Sports hall; Cultural } \\
\text { house; career center; } \\
\text { youth center; local youth } \\
\text { action council }\end{array}$ & Yes \\
\hline Gllogoc & $\begin{array}{l}\text { Volunteerism; Local } \\
\text { economic development; } \\
\text { Inclusion of Youth in } \\
\text { decision making; Paid } \\
\text { internships; }\end{array}$ & $\begin{array}{l}\text { Construction engineer; Architect } \\
\text { Environmentalist; } \\
\text { development/management (assigned for youth- } \\
\text { oriented projects) }\end{array}$ & $8.50 \%$ & $\begin{array}{l}\text { Sports hall; Cultural } \\
\text { house; youth center; local } \\
\text { youth action council }\end{array}$ & No \\
\hline
\end{tabular}




\section{CONCLUSION}

An overarching conclusion stemming from the analysis is that all ten municipalities assessed do not have a specific code related to financing youth activities. All ten municipalities have noted that they need capacity building, and on the type of support needed for the project implementation, the following were identified as most pressing capacity-building needs:

- Volunteerism, nine out of ten municipalities;

- Paid internships for specific position/profiles, ten out of ten municipalities;

- Inclusion of Youth in decision making, nine out of ten municipalities;

- Local economic development, nine out of ten municipalities;

- Gender equality/representation;

- Services provided by municipalities related to culture, youth, and sports, including sports facilities

Assessments indicated that municipalities also require Youth-related community facility improvements (e.g., repair and enhancement of youth centers, parks, classrooms, youthfriendly spaces in health centers and libraries).

All ten municipalities have declared the need for support on capacities to supervise works and technical acceptance of projects. At the same time, there is a considerable capacity for sub-project implementation assessment/evaluation of Youth-related projects and activities.

There are three potential gaps identified: 1) competitive and transparent sub granting processes within the municipalities regarding youth-oriented projects and 2) demand-driven youth programming - capacity to respond to youth needs through targeted services subproject and other youth activities and 3) improvement of youth orientation of general services (e.g., use of social media, youth-oriented marketing of services/activities, enhanced collaboration with youth on monitoring public services, etc.). 


\section{ANNEXES}

Annex 1. List of interviews

\begin{tabular}{|c|c|c|c|}
\hline Nr. & Municipality & Person & Position \\
\hline 1. & Zvecan & Milan Radomirovic & $\begin{array}{l}\text { Director of Youth and Sport } \\
\text { Dep. }\end{array}$ \\
\hline 2. & Kaçanik & Fatmir Qaka & $\begin{array}{l}\text { Coordinator for Youth, Culture } \\
\text { and Sports. }\end{array}$ \\
\hline 3. & Hani i Elezit & Refki Suma & Mayor of municipality \\
\hline 4. & Hani i Elezit & Mazllum Qajani & Deputy mayor of Municipality \\
\hline 5. & Hani i Elezit & Menduh Vlashi & $\begin{array}{l}\text { Director of Education, Youth } \\
\text { and Sport Dep. }\end{array}$ \\
\hline 6. & Skenderaj & Arben Mehmeti & $\begin{array}{l}\text { Director of Youth and Sport } \\
\text { Dep }\end{array}$ \\
\hline 7. & Gllogoc & Arben Shala & Deputy Mayor of Gllogoc \\
\hline 8. & Gllogoc & Shqipe Zogu & $\begin{array}{l}\text { Director of Youth and Sport } \\
\text { Dep. }\end{array}$ \\
\hline 9. & Gllogoc & Kajtaz Kastrati & $\begin{array}{l}\text { Official on Youth and Sport } \\
\text { Dep. }\end{array}$ \\
\hline 10. & Junik & Leonita Jasiqi & Director of Administration \\
\hline 11. & Junik & Hasan Krasniqi & Director of Urbanism \\
\hline 12. & Rahovec & Fatmir Iska & Deputy Mayor of Municipality \\
\hline 13. & Rahovec & Muharem Morina & $\begin{array}{l}\text { Official for youth, culture and } \\
\text { sports }\end{array}$ \\
\hline 14. & Ranillug & Vladica Aritonovic & Mayor of Municipality \\
\hline 15. & Ranillug & Aleksandra Nikolić & Chief of Mayors cabinet \\
\hline 16. & Ferizaj & Arton Kavazi & Deputy mayor of Municipality \\
\hline 17. & Ferizaj & Agron Zhilipotoku & Chief of Youth and Sport Dep. \\
\hline 18. & Ferizaj & Xhemile Murati & Director Youth and Sport Dep. \\
\hline 19. & Ferizaj & Flamur Sallahu & $\begin{array}{l}\text { Official from Youth and Sport } \\
\text { Dep }\end{array}$ \\
\hline 20. & Vushtrri & Arta Ismajli & Director Youth and Sport Dep \\
\hline
\end{tabular}




\section{Annex 2. The questionnaire with municipal officials}

Municipality:

Mayor of the municipality:

Tel:

E-mail:

1. Does your Municipality need capacity building support?

\section{YES $\square$}

2. In which sectors does your municipality need more support in the implementation of youth projects?

$\square$ Voluntarism

$\square$ Human rights

$\square$ Equality

$\square$ Local economic recovery

$\square$ Inclusion in decision making processes

$\square$ Paid internships

$\square$ Other?

3. Identify positions where paid internships in your municipality would help improve performance and provide services to young people more effectively.

$\square$ Civil engineer

Architect

$\square$ Financier

$\square$ Environmentalists

Social worker 
Project developer

$\square$ Other?

4. To what $\%$ does your municipality allocate the annual municipal budget to the youth sector?

- Amount $\%$

5. What youth services and facilities does your Municipality have?

- Sports center

- Cultural Center

- Career development center

- Youth Center

- Local Youth Action Council

- University

- Other

6. Does your municipality have sufficient capacity to cover the responsibility for supervising the works and technical acceptance of youth projects?

YES $\square \quad$ NO

7. If not, what is your proposal for capacity building of the municipality in the supervision of works / technical acceptance of projects?

8. Does your municipality have the capacity to evaluate projects supported by public funds?

YES

NO 


\section{REFERENCES}

Ahmeti, S. S., \& Fejza, M. S. E. (2011). Own source revenues of Kosovo municipalities and their impact on effective services. ILIRIA International Review, 1(2).

Feltes, T. (2013). Youth and democracy: The promotion of youth participation by the international community in Kosovo. Security and Human Rights, 24(2), 195-209.

Gashi, K., \& Krasniqi, A. D. I. The One-Stop Shop Approach: New Public Management Model in Transition Countries.

Jackson, D. (2018). Explaining municipal governance in Kosovo: local agency, credibility, and party patronage. Southeast European and Black Sea Studies, 18(2), 165-184.

Krasniqi, S., \& Krasniqi, E. H. (2015). Pristina's development strategy of 2013-2016: An analysis of the situation in the educational, cultural, youth, and sport sector. European Scientific Journal, 11(19).

Kosovo Agency of Statistics (2011) Country Census- Estimation of Kosovo Population, available at: https://ask.rks-gov.net/media/2129/estimation-of-kosovo-population-2011.pdf Le, H. T. (2017). The potential of youth participation in Pristina, Kosovo. Ministry of Local Governance Administration (2019), Municipal Performance Report, available at: https://mapl.rks-gov.net/en/mlga-annual-reports/

Ministry of Local Governance Administration (2020), Municipal Performance Report, available at: https://mapl.rks-gov.net/en/news/the-report-on-the-allocation-of-the-municipalperformance-grant-2020-is-published/

Ministry of Local Governance Administration (2020), Regulation No.01 / 2020 on the Municipal Performance Management System, available at: https://mapl.rks-gov.net/wpcontent/uploads/2020/07/Rregullorja-per-performance-453-470-2020-2.pdf

Official Gazette of the Republic of Kosovo (2008), Constitution of the Republic of Kosovo, Government of Republic of Kosovo: Pristina

Official Gazette of the Republic of Kosovo (2008), Law on Cultural Heritage, Government of Republic of Kosovo: Pristina

Official Gazette of the Republic of Kosovo (2008), Law on Education in the Municipalities, Government of Republic of Kosovo: Pristina

Official Gazette of the Republic of Kosovo (2008), Law on Local Self Government (No. 03/L-040, 2008), Government of Republic of Kosovo: Pristina

Official Gazette of the Republic of Kosovo (2008), Law on the Civil Service, Government of Republic of Kosovo: Pristina 
Official Gazette of the Republic of Kosovo (2008), Law on Use of Languages, Government of Republic of Kosovo: Pristina

Official Gazette of the Republic of Kosovo (2008), The Anti-Discrimination Law, Government of Republic of Kosovo: PristinaPerritt Jr, H. H. (2010). The road to independence for Kosovo: a chronicle of the Ahtisaari plan. Cambridge University Press.Qosaj-Mustafa, Ariana. "Kosovo." Nations in Transit report, Freedom House, Washington DC (2011).

Rexhepi, N., \& Murati, V. Youth Employment in Kosovo: Present Commitments and Future Goals and Perspectives.

Strøm, K., Gates, S., Graham, B., \& Strand, H. (2017). Inclusion, dispersion, and constraint: power-sharing in the world's states, 1975-2010. British Journal of Political Science, 47(1), 165-185.

Ismajli, N., Zekiri, J., Qosja, E., \& Krasniqi, I. (2015). The importance of motivation factors on employee performance in Kosovo municipalities. Journal of Political Sciences \& Public Affairs

Shala, M. (2016). Supervision and Control of Local Governance in the Republic of Kosovo. European Journal of Interdisciplinary Studies, 2(1), 40-50.

United Nations (1976) International Covenant on Economic, Social and Cultural Rights, New York city, United Nations General Assembly. United Nations (1999), United Nations Mission in Kosovo Regulation No. 2000/45 on Self-Government of Municipalities in Kosovo. United Nations

Vaillancourt, F. Local Government in Kosovo. The Kosovo Decentralization Briefing Book, 19. 